\title{
Simultaneous removal of selenite and selenate from drinking water using mesoporous activated alumina
}

\author{
Alok Kumar Meher ${ }^{1} \cdot$ Asmita Jadhav $^{1} \cdot$ Nitin Labhsetwar $^{1} \cdot$ Amit Bansiwal $^{1}$
}

Received: 13 February 2017 / Accepted: 30 October 2019 / Published online: 18 November 2019

(c) The Author(s) 2019

\begin{abstract}
The present study reports detailed evaluation of mesoporous activated alumina (MAA) for simultaneous removal of two hazardous inorganic species of selenium, namely selenite and selanate, from drinking water. MAA was used after washing with deionized water followed by drying at $110^{\circ} \mathrm{C}$ for $8 \mathrm{~h}$. The material was characterized using pXRD, FTIR, zeta potential, SEM and BET surface area measurements. Batch adsorption studies were performed, and various adsorption isotherms and kinetic parameters were computed to delineate the mechanism of adsorption. It was observed that Freundlich adsorption isotherm was the best-fit model for both the species of selenium. The adsorption capacity obtained from Freundlich isotherm for selenite and selenate was found to be $9.02 \mu \mathrm{g} \mathrm{g}^{-1}$ and $5.38 \mu \mathrm{g} \mathrm{g}^{-1}$, respectively. Kinetics studies revealed that adsorption of selenite follows pseudo-second-order model, whereas selenate adsorption follows pseudo-first-order model. The efficiency of the material was also evaluated at different $\mathrm{pH}$ and in the presence of different competitive co-ions, which confirms efficacy of MAA at near-neutral $\mathrm{pH}$ and lower concentrations of competitive co-ions. Negligible changes in the $\mathrm{pH}$ were observed during the course of adsorption. Further, the saturated adsorbent was subjected to regeneration and reuse studies up to ten cycles, showing insignificant reduction in adsorption efficiency of the adsorbent during few initial cycles. The study infers the effectiveness of MAA as a potential adsorbent for drinking water treatment contaminated with selenium.
\end{abstract}

Keywords Adsorption $\cdot$ Selenite $\cdot$ Selanate $\cdot$ Mesoporous activated alumina $\cdot$ Drinking water

\section{Introduction}

Selenium is one of the micronutrients for living organisms, but is one of the major concerns due to narrow range between deficit and toxicity levels (Goldhaber 2003). Selenium-contaminated sites are distributed worldwide, with wide range of variation in selenium concentration. The presence of elevated concentration of selenium has also been reported in India $\left(2.3-11.6 \mathrm{mg} \mathrm{kg}^{-1}\right)$, particularly from the

Nitin Labhsetwar

nk_labhsetwar@neeri.res.in

$\checkmark$ Amit Bansiwal

ak_bansiwal@ neeri.res.in

Alok Kumar Meher

ak_meher@neeri.res.in

Asmita Jadhav

asmi.jadhav229@gmail.com

1 Environmental Materials Division, CSIR-National Environmental Engineering Research Institute (CSIRNEERI), Nehru Marg, Nagpur 440020, India
Northern parts such as Punjab (Bajaj et al. 2011). Apart from natural sources, anthropogenic sources such as mining operations, application of fertilizer and oil refining can considerably enhance the selenium content in ground water.

Selenium has been reported for its potential toxicity with threats to both wildlife and human health (Hamilton 2004). The International Agency for Research on Cancer (IARC) classified selenium as a Group-3 carcinogen (Anonymous 2015a, b). Considering its adverse effects on human health, regulatory authorities such as the WHO (Anonymous 2015) have framed a strict permissible limit of $10 \mu \mathrm{g} \mathrm{L}^{-1}$ for selenium in drinking water, and this standard has been widely adopted by USEPA (Anonymous 2012), Australia (Anonymous 2011), Japan (Anonymous 2004), India (Anonymous 2012) and Canadian guideline value of $50 \mu \mathrm{g} \mathrm{L}^{-1}$ (Anonymous 2014).

In natural environments, selenium mainly exists in two dominant inorganic species, namely selenate $\left(\mathrm{SeO}_{4}{ }^{2-}\right)$ and selenite $\left(\mathrm{SeO}_{3}{ }^{2-}\right)$. The most mobile forms of selenium in soil, groundwater and seawater are selenite and selenate. Selenium remains in oxyanion form of selenite $\left(\mathrm{SeO}_{3}{ }^{2-}\right)$ at 
acidic condition, but at neutral and alkaline range selenate $\left(\mathrm{SeO}_{4}{ }^{2-}\right)$ is the dominant form. The oxyanion species are water soluble and, especially, the selenate is prone to less adsorption onto soil surfaces and hence more tendency to leach into the aqueous phase. However, mobility, bioavailability and speciation of selenium species are highly dependent on $\mathrm{pH}$ and redox conditions. Selenite has been found to be more toxic than selenate and organo-selenium compounds, due to its higher solubility and bioavailability (Torres et al. 2011).

Various treatment technologies such as lime softening, precipitation/filtration, coagulation, ferrous hydroxide reduction, biological reduction, algal volatilization, reverse osmosis, emulsion liquid membranes, nanofiltration, electro-coagulation and adsorption (Cohen 2006; Smith et al. 2009; Mavrov et al. 2006; Geoffroy and Demopoulos 2011; Butler 2010; Twidwell et al. 1999; CH2 M HILL 2010) have been extensively studied to remove different forms of selenium from contaminated water. Among all the technologies, adsorption provides the better suitability due to its high efficiency, cost-effectiveness and less energy input for operation, socio-cultural acceptance and regulatory compliance (Mohan and Pittman 2007; Ali 2012). Nanomaterials are a class of adsorbents, with some unique properties, namely high surface-to-volume ratio, large numbers of active sites for interaction with pollutants, ease of separation from the bulk separation, which makes them a preferable option for the removal of a diverse class of pollutants from water (Burakov et al. 2018; Ali 2012).

Extensive research has been therefore carried out on comparative adsorption of selenate and selenite on a variety of adsorbents ranging from activated carbon to mineral oxides, and it has been reported that selenate is relatively weakly bound, while selenite forms very strong complexes. Some of the promising reported adsorbents for selenite are Ferrihydrite, Goethite, lepidocrocite (Das et al. 2013), zerovalent iron (Ling et al. 2015), metal oxides (Chan et al. 2009), bentonite (Wang et al. 2015); metal hydroxyl-vermiculite complex (Wei 2012), activated carbon and surface modified activated carbon (Yan et al. 2013; Wasewar et al. 2009a, b), chitosan-clay composite (Bleiman and Mishael 2010), maghemite (Jordan et al. 2013), magnetite (Wei et al. 2012), granite (Jan et al. 2008), $\mathrm{TiO}_{2}$ ( $\mathrm{Zhang}$ et al. 2009), aluminum oxide-coated sand (Kuan et al. 1998a, b), layered double hydroxides (Goh and Lim 2010), lanthanum and aluminum-based oxides (Davis and Misra 1997), pea nut shell (El-Shafey 2007), mackinawite (Han et al. 2011). Certain conjugate ligand-based adsorbents such as 3-(3-(methoxycarbonyl)benzylidene)hydrazinyl)benzoic acid (MBHB) ligand-based adsorbent, mesoporous silica-based adsorbent are used for efficient selenite detection and removal from water (Awual et al. 2014, 2015). However, they are ineffective for removal of selenate, as well there are few reports for selenate removal from water, which is the predominant selenium species in the drinking water.

Activated alumina has been suggested by the USEPA as one of the best available treatment technologies for removal of selenium from drinking water (USEPA 1980; CH2 M HILL 2010). Amphoteric property of activated alumina makes it one of the best choices for water and wastewater treatment systems. Some of the major advantages for the use of activated alumina as adsorbent are abundant availability, low cost, minimum operator attention and ease of operation. Activated alumina has been widely reported to adsorb many oxyanions (Su et al. 2008, 2010; Singh and Pant. 2004). Many workers have attempted to adsorb selenite and selenate on the surface of activated alumina (Rajan 1979; Yuan 1984; Batista and Young 1994, 1997; Papelis et al. 1995; Hornung et al. 1983; Jegadeesan et al. 2003, 2005; Trussell et al. 1980; Ghosh et al. 1994). The conclusion is that activated alumina shows very good efficiency for selenite, but inefficient for the selenate, which is the dominated species in groundwater. Further, selectivity of activated alumina for selenate is very poor. Many researchers reported that sulfate and bicarbonate have no effect on selenite adsorption, but these co-ions can significantly interfere for adsorption of selenate. These challenges may be overcome by application of engineered mesoporous materials, which have the key advantage of high surface area, controlled pore size and ease of accessibility to surface functionalization. Several reports suggest the application of mesoporous materials significantly enhances adsorption efficiency with a better selectivity for oxyanions and other water pollutants (Kim et al. 2004; Pillewan et al. 2011; Mercier and Pinnavaia 1997).

The major objective of the present work is to evaluate the efficiency of mesoporous activated alumina (MAA) for simultaneous removal of selenite and selenate. Other objectives include delineation of various adsorption and kinetic parameters to determine the adsorption efficiency and to estimate the rate of reaction to understand the mechanism of adsorption. The effect of $\mathrm{pH}$ and presence of competitive co-ions on the selenium adsorption have also been studied. Regeneration study was also performed in order to access the suitability of the adsorbent for field application to real drinking water treatment systems.

\section{Materials and methods}

\section{Materials}

Mesoporous activated alumina (MAA) used for the present work was procured from SASOL, GmbH Germany (Grade PURALOX). Spherical beads of alumina were used after washing with deionized (DI) water (18 $\mathrm{M} \Omega$ resistivity, obtained from MilliQ DI water system), without any 
chemical treatment. Analytical reagents such as sodium chloride, sodium nitrate, sodium sulfate, sodium carbonate and sodium bicarbonate were purchased from E. Merck India Ltd. Commercially available standard solutions of selenite and selanate of concentrations $1000 \mathrm{mg} \mathrm{L}^{-1}$ were purchased from Inorganic Ventures, USA. Working solution concentration of $200 \mu \mathrm{g} \mathrm{L}^{-1}$ of selenite and selenate was prepared by dilution with DI water.

\section{Material characterization}

Powder X-ray diffraction (XRD) measurement was carried out using a bench-top X-ray Diffractometer (Model Rigaku Miniflex, Japan) operated with $\mathrm{Ni}$-filtered $\mathrm{Cu} \mathrm{K} \alpha$ radiation at $30 \mathrm{kV}$ and $15 \mathrm{~mA}$. The samples were scanned at $2 \theta$ ranges from $5^{\circ}$ to $80^{\circ}$ using a step size of $2^{\circ} \mathrm{min}^{-1}$. The FTIR spectra were recorded by using Fourier-transform infrared (FTIR) spectroscopy (Bruker, Model Vertex-70, Germany) to identify the nature and type of functional groups formed on the adsorbent surface. Sample was scanned in the range of $400-4000 \mathrm{~cm}^{-1}$. The SEM micrographs were taken using a Stereo scan S250 MK3 (Cambridge Instruments, UK) instrument operating at $25 \mathrm{kV}$ to characterize the morphology of the particles. BET surface area measurements were carried out using Micrometrics ASAP $2010 \mathrm{~K}$ surface area and pore size analyzer to evaluate the reactive surface areas using standard multipoint nitrogen adsorption isotherms. Zeta potential was measured using a zeta analyzer (Nanoparticle analyzer, Horiba scientific, Japan) using light scattering method. The colloidal solution of alumina was prepared in deionized water having a conductivity of $<2 \mu \mathrm{S} \mathrm{cm}^{-1}$. The zeta potential was calculated using Smoluchowski's method.

\section{Methods}

\section{Adsorption studies and isotherms}

Batch adsorption study was carried out by varying the adsorbent dose. Different doses of MAA were suspended in a $250 \mathrm{ml}$ polypropylene conical flask in the presence of $100 \mathrm{ml}$ of analyte solution concentration of $200 \mu \mathrm{g} \mathrm{L}^{-1}$. The $\mathrm{pH}$ of the suspension was adjusted at neutral condition and placed at orbital shaker (Maker: Remi) for $12 \mathrm{~h}$ at $25^{\circ} \mathrm{C}$. Filtration was done, and the filtrate was collected for further analysis. The percent removal of selenium for each adsorbent dose was calculated by the following formula:

$\%$ Removal $=\left(C_{\mathrm{o}}-C_{\mathrm{e}}\right) / C_{\mathrm{o}} * 100$

where $C_{\mathrm{o}}$ is the initial concentration and $C_{\mathrm{e}}$ is the final concentration.
In the present study, we have considered two adsorption isotherm models, namely Langmuir and Freundlich isotherms. Langmuir equation is derived from mass kinetics, assuming the monolayer adsorption of the adsorbate at homogenous active sites of the adsorbent. The linear form can be represented as follows (Langmuir 1916):

$\frac{1}{q_{\mathrm{e}}}=\frac{1}{q_{\mathrm{m}} K_{\mathrm{L}} C_{\mathrm{e}}}+\frac{1}{q_{\mathrm{e}}}$

Similarly, adsorption at heterogeneous sites of an adsorbent with multilayer adsorption can be defined by the Freundlich model. The linear form of Freundlich adsorption model may be represented as follows (Freundlich 1906): $\log \left(q_{\mathrm{e}}\right)=\log k+\frac{1}{n} \log \left(C_{\mathrm{e}}\right)$. where $q_{\mathrm{e}}$ denotes the amount of adsorbate adsorbed per unit weight of adsorbent at equilibrium $\left(\mathrm{mg} \mathrm{g}^{-1}\right), q_{\mathrm{m}}$ denotes the maximum adsorption capacity $\left(\mathrm{mg} \mathrm{g}^{-1}\right), K_{\mathrm{L}}$ denotes the Langmuir constant, $C_{\mathrm{e}}$ denotes the equilibrium concentration of adsorbate in solution $\left(\mathrm{mg} \mathrm{L}^{-1}\right)$, $K_{\mathrm{f}}$ denotes the Freundlich constant, $n$ denotes the Freundlich constant, which reflects adsorption intensity and $Q_{m}$ denotes the theoretical adsorption capacity $\left(\mathrm{mg} \mathrm{g}^{-1}\right)$.

\section{Kinetics study}

Kinetics study was performed by adding the optimal dose of the adsorbent at an initial concentration of $200 \mu \mathrm{g} \mathrm{L}^{-1}$. The suspension was agitated by a laboratory mechanical stirrer, and filtrates were collected at predetermined time intervals. Residual analyte concentrations were estimated in the filtrate.

The experimental data observed from kinetics studies were fitted into pseudo-first-order and pseudo-secondorder models. The linear form of pseudo-first-order kinetic model (Lagergren equation) may be represented as (Lagergren 1898):

$\ln \left(q_{\mathrm{e}}-q_{\mathrm{t}}\right)=\ln q_{\mathrm{e}}-K_{\mathrm{a}} d_{\mathrm{t}}$

where $q_{\mathrm{t}}$ and $k_{\text {ad }}$ are the amount of selenium adsorbed at time $t\left(\mathrm{mg} \mathrm{g}^{-1}\right)$ and the equilibrium rate constant of pseudo-firstorder adsorption $\left(\mathrm{min}^{-1}\right)$, respectively. The linearized plots of $\log \left(q_{\mathrm{e}}-q_{\mathrm{t}}\right)$ versus $t$ give the rate constants.

The linear equation of pseudo-second-order model may be written as: Ho and McKay (1999)

$\frac{t}{q_{\mathrm{e}}}=\frac{1}{h}+\frac{t}{q_{\mathrm{e}}}$

And

$h=k q_{\mathrm{e}}^{2}$ 
where $q_{\mathrm{e}}$ is the amount of selenium adsorbed at equilibrium $\left(\mathrm{mg} \mathrm{g}^{-1}\right)$ and $h$ is the initial sorption rate $\left(\mathrm{mg} \mathrm{g}^{-1} \mathrm{~min}^{-1}\right)$. The values of $q_{\mathrm{e}}$ (1/slope), $k$ (slope ${ }^{2} /$ intercept) and $h$ (1/intercept) can be calculated from the plots of $t / q_{\mathrm{t}}$ versus $t$.

\section{Pore diffusion study}

Sorption of an adsorbate on porous solid adsorbent can also be modeled by pore diffusion models, which can be either interparticle diffusion or intraparticle pore diffusion model. The linear form of Interparticle diffusion model can be represented as (Weber and Morris 1987):

$\ln \left(\frac{C_{\mathrm{t}}}{C_{\mathrm{e}}}\right)=-k_{p} t$

where $k_{\mathrm{p}}$ denotes the particle diffusion coefficient $\left(\mathrm{mg} \mathrm{g}^{-1}\right.$ min), which ${ }_{p}$ can be obtained by slope of the plot between $\ln \left(C_{\mathrm{t}} / C_{\mathrm{e}}\right)$ and $t$.

The intraparticle pore diffusion model or the Weber and Morris plot can be written as (Weber and Morris 1987):

$q_{\mathrm{t}}=k_{i} t^{5}$

where $k_{\mathrm{i}}$ denotes the intraparticle diffusion coefficient $\left(\mathrm{mg} \mathrm{g} \min ^{0.5}\right.$ ), which can be obtained from the slope of plot of $q_{\mathrm{t}}$ verses $t^{1 / 2}$.

\section{Effect of pH on adsorption}

Affinity of the adsorbent was evaluated at a broad range of $\mathrm{pH}$ ranging from 4 to 9 . Optimal dose of the adsorbent was taken, and $\mathrm{pH}$ of the suspension was maintained by addition of $\mathrm{NaOH}$ or $\mathrm{HCl}$. After $12 \mathrm{~h}$ of shaking, filtrates were collected and residual analyte concentrations were measured.

$\mathrm{pH}$ of the solution was also monitored during the course of adsorption. Five hundred milliliters of the solution was prepared at an initial analyte concentration of $200 \mu \mathrm{g} \mathrm{L}^{-1}$, and optimal dose of the adsorbent was added to it. $\mathrm{pH}$ value was recorded at a time interval of $30 \mathrm{~min}$ by a freshly calibrated pH meter (PCT 35, Eutech).

\section{Effect of presence of other ions}

The effect of interfering ions, which are normally present in drinking water, was studied in two ways. In one case, tap water was spiked with $200 \mu \mathrm{g} \mathrm{L}{ }^{-1}$ of the analytes (TW), and in another case spiking of the analytes was done in simulated water (SW), which was prepared with the composition of chloride $100 \mathrm{mg} \mathrm{L}^{-1}$, bicarbonate $50 \mathrm{mg} \mathrm{L}^{-1}$, carbonate $200 \mathrm{mg} \mathrm{L}^{-1}$, phosphate $1 \mathrm{mg} \mathrm{L}^{-1}$ and sulfate $20 \mathrm{mg} \mathrm{L}^{-1}$. Adsorption studies were conducted at optimal dose to evaluate the effect of presence of co-ions.

\section{Regeneration of saturated adsorbent}

MAA was saturated with the analyte with an initial analyte concentration of $200 \mu \mathrm{g} \mathrm{L}{ }^{-1}$ at optimal dose. Regeneration studies were conducted by shaking the required quantity of saturated adsorbent for $1 \mathrm{~h}$ with regenerant, i.e., $\mathrm{NaOH}$. After each cycle, the adsorbent was subjected to proper washing with deionized water. Weight loss during each regeneration cycle was also calculated. Concentration of the $\mathrm{NaOH}$ and time was optimized for determining optimum conditions for effective regeneration.

\section{Analysis of selenium}

Concentrations of selenite and selenate were analyzed by inductively coupled plasma-mass spectrometer (ICP-MS, NexIon 300, PerkinElmer, USA) by external calibration method. Standard NIST traceable selenium solutions of concentration $1000 \mathrm{mg} \mathrm{L}^{-1}$ were procured from Inorganic Ventures, USA, and working standard solutions of concentrations of $5 \mu \mathrm{g} \mathrm{L}{ }^{-1}, 10 \mu \mathrm{g} \mathrm{L}^{-1}, 30 \mu \mathrm{g} \mathrm{L}^{-1}, 50 \mu \mathrm{g} \mathrm{L}^{-1}$, $100 \mu \mathrm{g} \mathrm{L}^{-1}, 150 \mu \mathrm{g} \mathrm{L}^{-1}$ and $200 \mu \mathrm{g} \mathrm{L}{ }^{-1}$ were prepared from the stock solution by serial dilutions. All the samples were analyzed at a minimum calibration coefficient of 0.9998 .

All the experiments were carried out in duplicate to minimize the manual error levels. Sorptions of analyte onto vials were assumed to be negligible.

\section{Results and discussion}

\section{Material characterization}

The pXRD pattern of MAA presented in Fig. 1 shows no sharp peaks, which suggest the typical amorphous nature

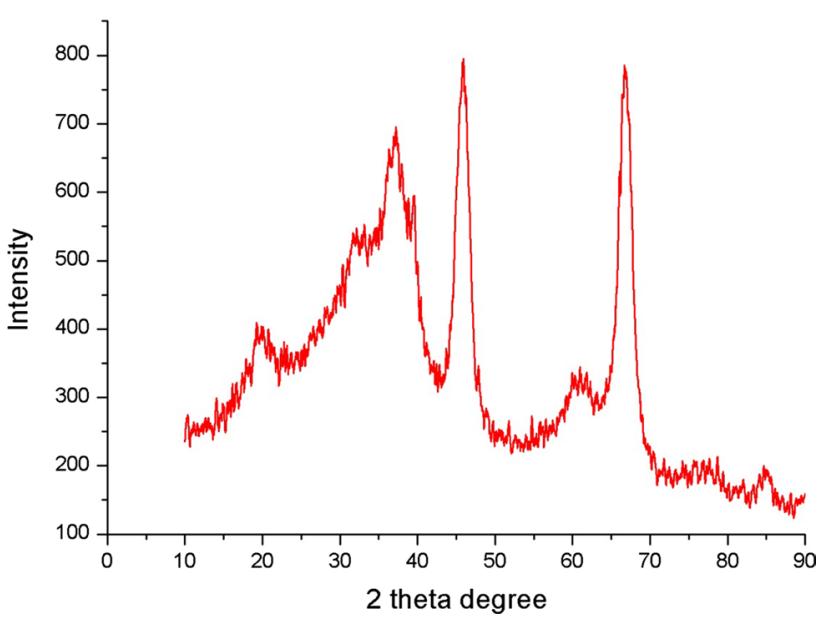

Fig. 1 pXRD patterns of MAA 


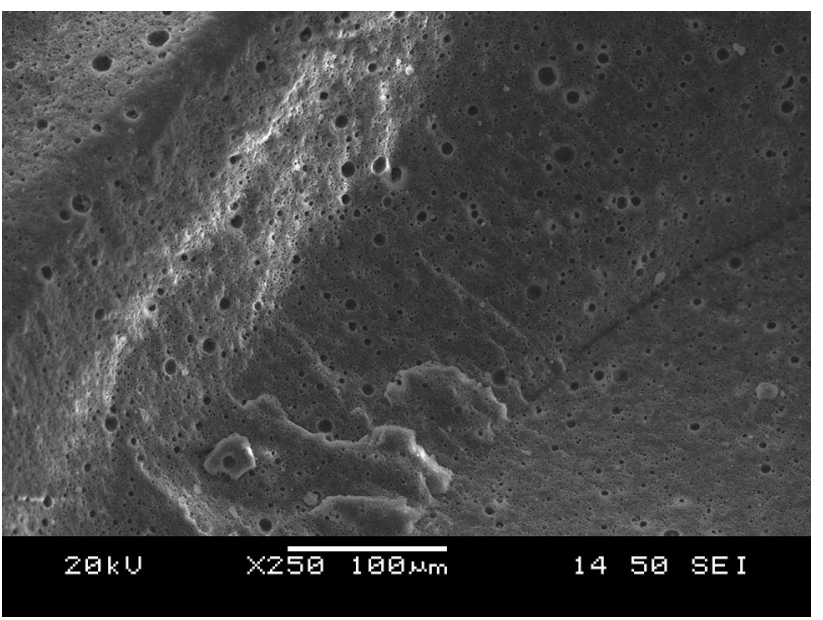

Fig. 2 SEM micrographs of MAA
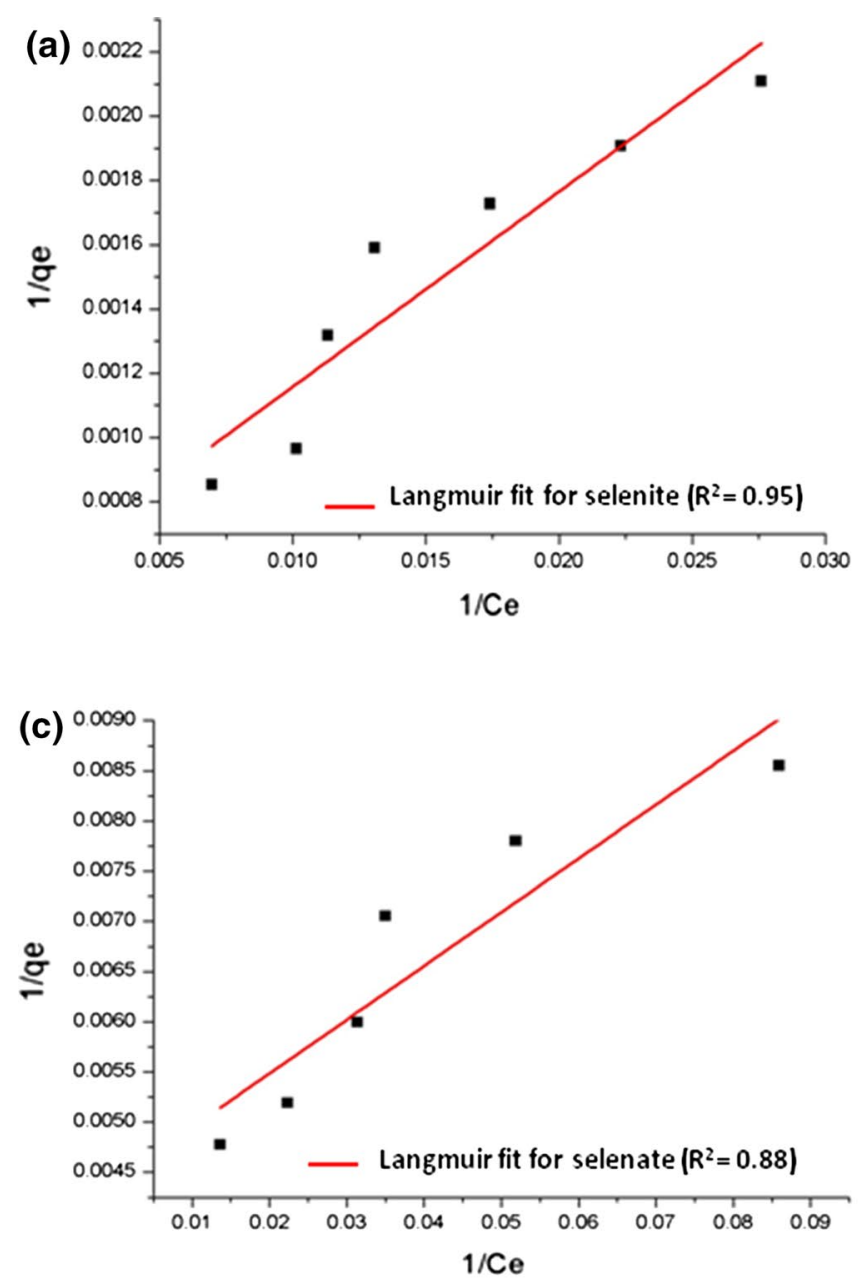

Fig. 3 Adsorption isotherms (batch volume $100 \mathrm{ml}$, temperature $30 \pm 2{ }^{\circ} \mathrm{C}$, initial Se concentration $200 \mu \mathrm{g} \mathrm{L}^{-1}$, contact time $12 \mathrm{~h}$ ). a Langmuir isotherm for selenite adsorption. b Freundlich isotherm for of alumina. Appearance of broad peaks at $2 \theta$ values of about $45^{\circ}, 35^{\circ}$ and $61^{\circ}$ confirms the presence of $\gamma$-alumina phases The SEM images presented in Fig. 2 show the highly porous surface morphology of MAA. Further, highly interlinked mesoporous channels were observed, which may lead to considerably high surface area for MAA than other forms of alumina. The MAA possess BET surface area of $189.12 \mathrm{~m}^{2} \mathrm{~g}^{-1}$ and pore volume of $0.4691 \mathrm{~cm}^{3} \mathrm{~g}^{-1}$. The adsorbent also shows average pore size of $98.63 \mathrm{~A}^{\circ}$, which further confirms the mesoporous nature of the alumina with higher surface area. Details of the material characterization have been discussed in some of the previously reported articles from our group (Bansiwal et al. 2010; Pillewan et al. 2011; Jain et al. 2015).

\section{Adsorption isotherms}

To determine the adsorption capacity and understand the nature of adsorption, a series of selenite and selenate
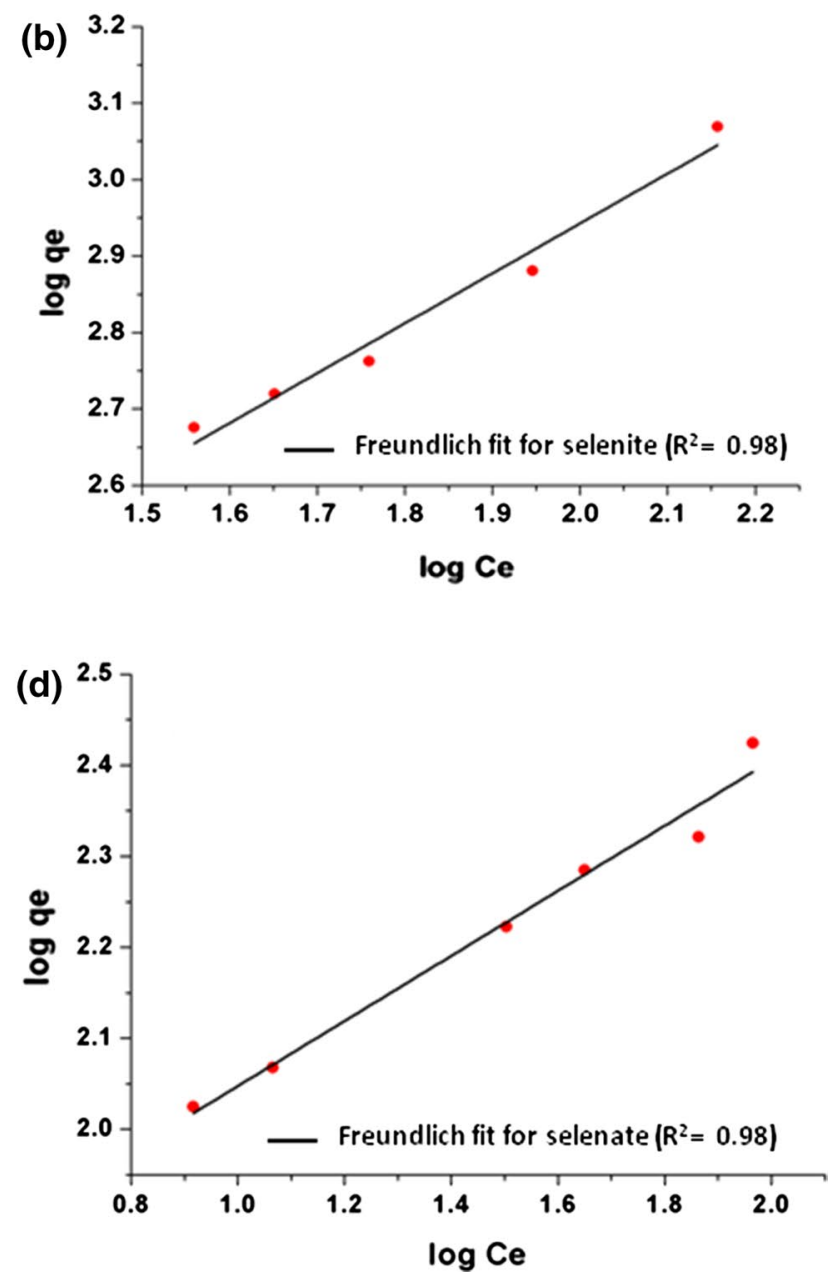

selenite adsorption. c Langmuir isotherm for selenate adsorption. d Freundlich isotherm for selenate adsorption 
Table 1 Parameters of Langmuir and Freundlich model for selenite and selenate adsorption onto MAA

\begin{tabular}{|c|c|c|c|c|c|c|}
\hline \multirow[t]{2}{*}{ Selenium species } & \multicolumn{3}{|c|}{ Langmuir model } & \multicolumn{3}{|c|}{ Freundlich model } \\
\hline & $q_{\mathrm{m}}\left(\mu \mathrm{g} \mathrm{g}^{-1}\right)$ & $r$ & $R^{2}$ & $K\left(\mu \mathrm{g} \mathrm{g}^{-1}\right)$ & $n$ & $R^{2}$ \\
\hline $\mathrm{Se}(+4)$ & 1666.67 & 0.33 & 0.95 & 9.02 & 1.53 & 0.98 \\
\hline $\mathrm{Se}(+6)$ & 142.85 & 0.01 & 0.88 & 5.38 & 5.00 & 0.98 \\
\hline
\end{tabular}

solutions were shaken by varying the dose of MAA at $25{ }^{\circ} \mathrm{C}$ for $12 \mathrm{~h}$. Adsorption data were fitted for Langmuir and Freundlich isotherms (Fig. 3 and Table 1). The higher value of correlation coefficient suggests better fitting for the Freundlich isotherm model for describing the adsorption of selenite and selenate on MAA, which confirms the heterogeneous nature of adsorption sites. The maximum adsorption capacity $(Q \max )$ for selenite and selenate by MAA obtained from Langmuir isotherm model was found to be $1666.67 \mu \mathrm{g} \mathrm{g}^{-1}$ and $142.85 \mu \mathrm{g} \mathrm{g}^{-1}$, respectively, whereas for Freundlich isotherms those values were $9.02 \mu \mathrm{g} \mathrm{g}^{-1}$ and $5.38 \mu \mathrm{g} \mathrm{g}^{-1}$ for selenite and selenate, respectively (Table 1 ). Comparative study of adsorption capacities between selenite and selenate species suggests better affinity toward selenite species. Many previous works also support that any adsorbent developed for removal of selenium species has better adsorption efficiency toward selenite than the selenate species (Chan et al. 2009; Han et al. 2011; Kuan et al. 1998a, b; Rovira et al. 2008).
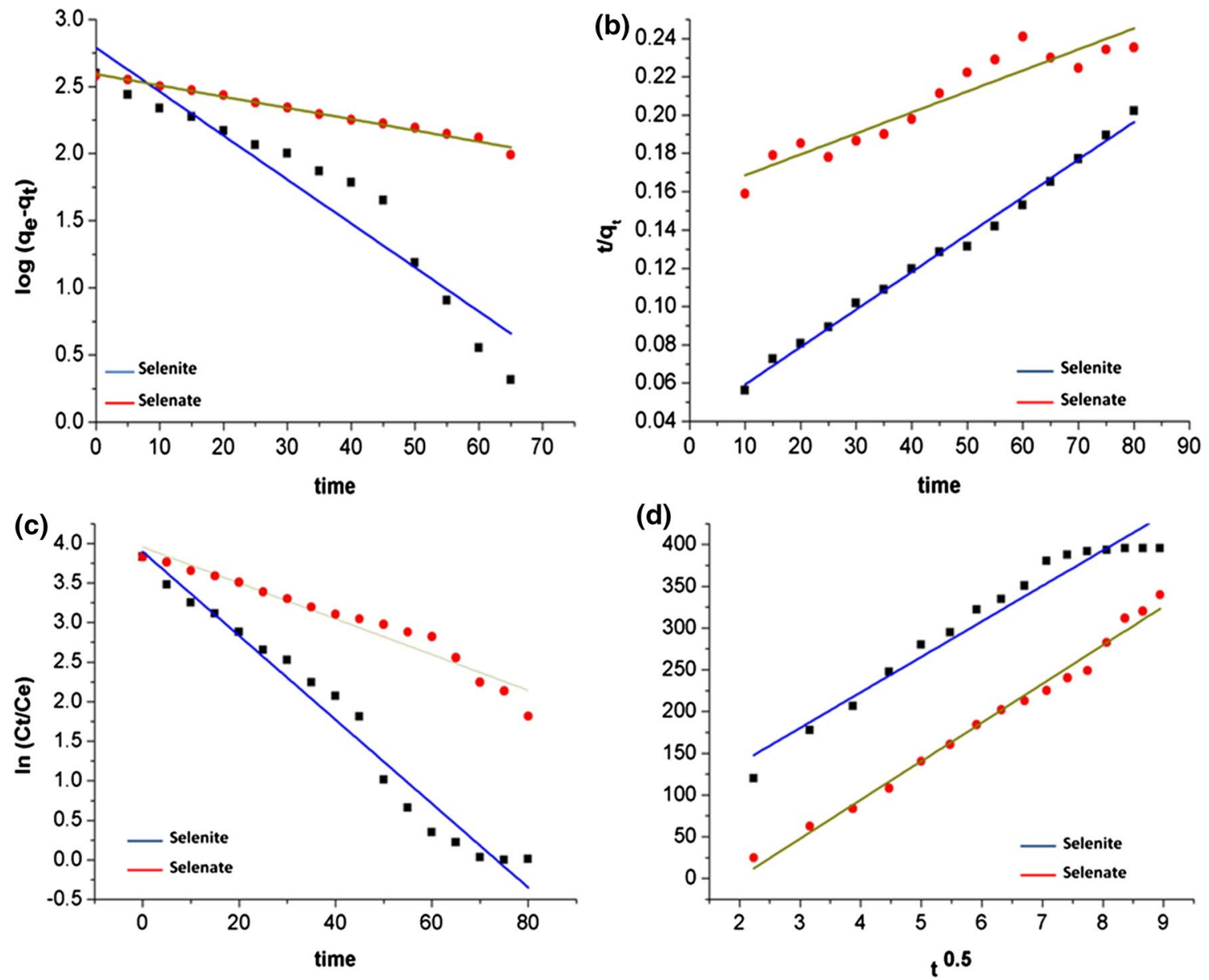

Fig. 4 Kinetics isotherms (volume $500 \mathrm{ml}$, temperature $30 \pm 2{ }^{\circ} \mathrm{C}$, initial Se concentration $200 \mu \mathrm{g} \mathrm{L}^{-1}$, adsorbent dose $0.5 \mathrm{~g} \mathrm{~L}^{-1}$ for selenite and $2.0 \mathrm{~g} \mathrm{~L}^{-1}$ for selenate). a Pseudo-first-order plot for selenite and selenate adsorption. b Pseudo-second-order plots for selenite and

selenate adsorption. c Plot for interparticle diffusion model for selenite and selenate adsorption. $\mathbf{d}$ Plot for intraparticle diffusion model selenite and selenate adsorption 
Table 2 Kinetics parameters for selenite and selenate adsorption onto MAA

\begin{tabular}{llllllll}
\hline Selenium species & \multicolumn{2}{l}{ Pseudo-first-order model } & & \multicolumn{3}{l}{ Pseudo-second-order model } \\
\cline { 2 - 3 } & $q_{\mathrm{e}}\left(\mu \mathrm{g} \mathrm{g}^{-1}\right)$ & $K\left(\mathrm{~min}^{-1}\right)$ & $R^{2}$ & & $q_{\mathrm{e}}\left(\mu \mathrm{g} \mathrm{g}^{-1}\right)$ & $K\left(\mathrm{~min}^{-1}\right)$ & $R^{2}$ \\
\hline $\operatorname{Se}(+4)$ & 30.67 & 0.001 & 0.91 & & 476.19 & 0.002 & 0.96 \\
$\mathrm{Se}(+6)$ & 63.28 & 0.001 & 0.99 & & 175.44 & 0.001 & 0.94 \\
\hline
\end{tabular}

Table 3 Diffusion parameters for selenite and selenate adsorption onto MAA

\begin{tabular}{llllll}
\hline Selenium species & \multicolumn{2}{l}{$\begin{array}{l}\text { Interparticle diffu- } \\
\text { sion model }\end{array}$} & & \multicolumn{2}{l}{$\begin{array}{l}\text { Intraparticle diffusion } \\
\text { model }\end{array}$} \\
\cline { 2 - 3 } & $K_{\mathrm{p}}\left(\mathrm{min}^{-1}\right)$ & $R^{2}$ & & $K_{\mathrm{t}}\left(\mathrm{g} \mathrm{\mu g} \mathrm{g}^{-1} \min ^{0.5}\right)$ & $R^{2}$ \\
\hline $\mathrm{Se}(+4)$ & 0.059 & 0.97 & 48.88 & 0.98 \\
$\mathrm{Se}(+6)$ & 0.029 & 0.95 & 10.53 & 0.97 \\
\hline
\end{tabular}

\section{Kinetics study}

Rate of adsorption of solute signifies the residence time of the sorption reaction and the potential rate controlling step, which are the important parameters for measurement of efficiency of adsorbent and mechanism of adsorption. Adsorption of selenite and selenate with respect to time reveals that equilibrium has been achieved at 70 and $120 \mathrm{~min}$ for selenite and selenate, respectively. The kinetics data have been fitted to pseudo-first-order and pseudosecond-order kinetic models (Fig. 4), and different kinetics parameters are presented in Table 2. The initial adsorption rate of selenite by MAA is $476.19 \mu \mathrm{g} \mathrm{g}^{-1} \mathrm{~h}^{-1}$, which is more than that of selenate $63.28 \mu \mathrm{g} \mathrm{g}^{-1} \mathrm{~h}^{-1}$. It was observed that for adsorption of selenite, the betterfitted model is pseudo-second-order model, but adsorption of selenate follows pseudo-first-order model. This is probably because selenite strongly bonds to the adsorbent surface via the formation of stronger inner-sphere complexes, whereas selenate binds weakly and takes more time to reach equilibrium in the slow process (Chan et al. 2009; Ford 1987).

The linear plots of particle diffusion and intraparticle pore diffusion models are also given in Fig. 4, for selenite and selenate, respectively. The values of different parameters are given in Tables 3, 4. Better fitting of intraparticle diffusion model for both selenite and selanate indicates that diffusion of adsorbate within the pores of adsorbent particle is contributing more toward rate determining step.

Table 4 Comparison of the MAA with other adsorbents

\begin{tabular}{|c|c|c|c|c|c|c|c|c|}
\hline Sr. no & $\begin{array}{l}\text { Name of the } \\
\text { adsorbent }\end{array}$ & $\begin{array}{l}\text { Adsorption capacity } \\
\left(\mathrm{mg} \mathrm{g}^{-1}\right)\end{array}$ & Selectivity & $\begin{array}{l}\text { Initial concen- } \\
\text { tration of } \\
\text { selenium }\end{array}$ & $\begin{array}{l}\text { Adsorption } \\
\text { isotherm } \\
\text { model fol- } \\
\text { lowed }\end{array}$ & $\begin{array}{l}\text { Kinetics } \\
\text { model fol- } \\
\text { lowed }\end{array}$ & Optimal pH & References \\
\hline 1. & $\begin{array}{l}\text { Hydrous } \\
\text { alumina } \\
\left(\gamma-\mathrm{Al}_{2} \mathrm{O}_{3}\right)\end{array}$ & - & $\begin{array}{l}\text { Selenite and } \\
\text { selenate }\end{array}$ & $0.1 \mathrm{mg} \mathrm{L}^{-1}$ & - & $\begin{array}{l}\text { Triple-layer } \\
\text { model }\end{array}$ & $5-8$ & $\begin{array}{l}\text { Ghosh et al. } \\
\text { (1994) }\end{array}$ \\
\hline 2. & $\gamma-\mathrm{Al}_{2} \mathrm{O}_{3}$ & $0.097 \pm 0.009 \mathrm{mg} \mathrm{g}^{-1}$ & Selenite & $5 \mathrm{mg} \mathrm{L}^{-1}$ & Langmuir & - & $\begin{array}{l}\text { Low } \mathrm{pH} \\
\quad(\mathrm{pH}<4)\end{array}$ & $\begin{array}{l}\text { Jegadeesan } \\
\text { et al. (2003) }\end{array}$ \\
\hline 3. & $\begin{array}{l}\text { Aluminum } \\
\text { oxide- } \\
\text { coated sand } \\
\text { (AOCS) }\end{array}$ & $0.92 \mathrm{mg} \mathrm{g}^{-1}$ & Selenate & $0.8 \mathrm{mM}$ & Langmuir & - & 0.92 & $\begin{array}{l}\text { Jegadeesan } \\
\text { et al. }(2005)\end{array}$ \\
\hline 4. & $\begin{array}{l}\text { Al-modified } \\
\text { bentonite }\end{array}$ & $60.1 \mathrm{mg} \mathrm{g}^{-1}$ & Selenite & $50 \mathrm{mg} \mathrm{L}^{-1}$ & Langmuir & - & 3 & $\begin{array}{l}\text { Wang et al. } \\
\text { (2015) }\end{array}$ \\
\hline 5 & MAA & $\begin{array}{l}9.02 \mu \mathrm{g} \mathrm{g}^{-1} \mathrm{Se}(\mathrm{IV}) \\
\text { and } 5.38 \mu \mathrm{g} \mathrm{g} \\
\mathrm{Se}(\mathrm{VI})\end{array}$ & $\begin{array}{l}\text { Selenite and } \\
\text { selenate }\end{array}$ & $200 \mu \mathrm{L}^{-1}$ & Freundlich & $\begin{array}{l}\text { Pseudo- } \\
\text { second order } \\
\text { and pseudo- } \\
\text { first order, } \\
\text { respectively }\end{array}$ & $6-8$ & Current study \\
\hline 6 & Goethite & $0.52 \mathrm{mg} \mathrm{g}^{-1}$ & $\begin{array}{l}\text { Selenite and } \\
\text { selenate }\end{array}$ & & Langmuir & $\begin{array}{l}\text { Pseudo-sec- } \\
\text { ond order }\end{array}$ & 4 & $\begin{array}{l}\text { Rovira et al. } \\
\text { (2008) }\end{array}$ \\
\hline
\end{tabular}




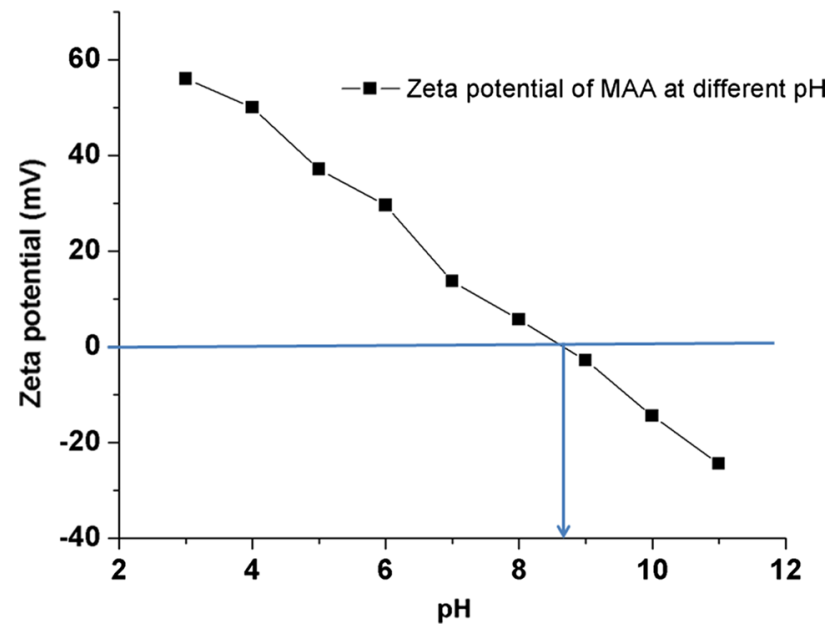

Fig. 5 Zeta potential of MAA at different solution $\mathrm{pH}$

\section{Effect of $\mathrm{pH}$ on adsorption}

From Eh-pH diagram for the $\mathrm{Se}-\mathrm{H}_{2} \mathrm{O}$ System, it is clear that selenium exists in as many oxyanionic forms such as $\mathrm{HSeO}_{4}{ }^{-}$at $\mathrm{pH}<2, \mathrm{HSeO}_{3}{ }^{-}$at $\mathrm{pH} 2$ to 7 and as $\mathrm{SeO}_{3}{ }^{-}$in alkaline $\mathrm{pH}$. The effect of $\mathrm{pH}$ on adsorption capacity of MAA may be inferred from the zeta potential values. The zeta potential measurements indicate that zeta potential of MAA was between +56.1 and $-24.4 \mathrm{mV}$ in the $\mathrm{pH}$ range of $3-11$. The isoelectric point obtained from the experimental data points was at $\mathrm{pH}$ of 8.6, which suggests that surface of the MAA has negative charge at $\mathrm{pH}$ above 8.4 and positive charge at near-neutral-to-acidic range (Fig. 5). Considering prevalent surface charges of the adsorbent and adsorbate and

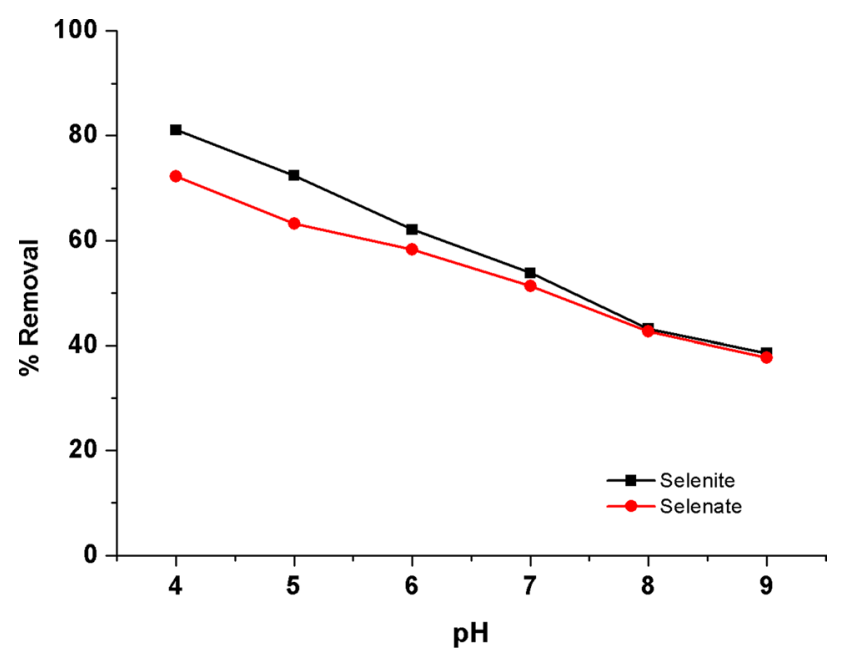

Fig. 6 Effect of $\mathrm{pH}$ on selenite and selenate adsorption by MAA (batch volume $100 \mathrm{ml}$, temperature $30 \pm 2{ }^{\circ} \mathrm{C}$, initial Se concentration $200 \mu \mathrm{g} \mathrm{L}^{-1}$, contact time $12 \mathrm{~h}$, adsorbent dose $0.5 \mathrm{~g} \mathrm{~L}^{-1}$ for selenite and $2.0 \mathrm{~g} \mathrm{~L}^{-1}$ for selenate) also according to observed zeta potential measurements, adsorption capacity of the MAA for selenite and selenite should decrease with increase in $\mathrm{pH}$.

To study the effect of $\mathrm{pH}$ on adsorption capacity of MAA, adsorption study was conducted at solution $\mathrm{pH}$ ranging from 4 to 9. As evident form Fig. 6, adsorption of both selenite and selenate has a strong correlation with variation in $\mathrm{pH}$. Removal of selenite has been reduced from $80.35 \%$ at $\mathrm{pH}$ of 4 to $38.22 \%$ at $\mathrm{pH}$ of 9 . Similarly, in the case of selenate the adsorption efficiency has been drastically reduced from 72.34 to $37.35 \%$, when $\mathrm{pH}$ of the solution was changed from 4 to 9 . This trend also agrees with the results obtained from zeta potential measurements. As per the reported literature, for most of the adsorbents, the adsorption capacity drastically reduces in alkaline pH (Das et al. 2013; Jordan et al. 2013; Wei et al. 2012; Su et al. 2008). The lowering of adsorption efficiency at the alkaline $\mathrm{pH}$ range may be due to competition of $\mathrm{OH}^{-}$at the active sites of the adsorbent.

The variation of $\mathrm{pH}$ with respect to time during adsorption process was also monitored. It was observed that during the course of adsorption of selenite, the supernatant $\mathrm{pH}$ was found to be almost stable, whereas in the case of selanate, $\mathrm{pH}$ increases slightly toward alkaline range. However, in both the cases the $\mathrm{pH}$ of the solution was in the permissible range of 6.5 to 8.5 for drinking purposes as per BIS- 10500 (Indian Drinking Water Standards), signifying the suitability of treated water for drinking purposes.

\section{Selectivity study}

The influence of several anions on adsorption efficiency of MAA for selenite and selanate removal was investigated. Chlorides, nitrates, carbonates, bicarbonate, sulfates and phosphate were selected as potential interfering anions as these are commonly found in natural water bodies. As per the Indian Standards (Anonymous 2012a, b) for drinking water (IS 10500:2012), the maximum acceptable limits for chlorides, nitrates, total alkalinity as carbonates and sulfates are $250 \mathrm{mg} \mathrm{L}^{-1}, 45 \mathrm{mg} \mathrm{L}^{-1}, 200 \mathrm{mg} \mathrm{L}^{-1}$ and $200 \mathrm{mg} \mathrm{L}^{-1}$, respectively. Selenite and selenate were spiked separately in DI water, tap water and simulated test water. In cases of spiking with tap water, no significant change in adsorption efficiency of MAA was observed. However, in simulated water, the presence of competitive ions at higher concentrations significantly affected the adsorption capacity. The adsorption capacity of MAA in SW was found to be lowered from 62.58 to $46.82 \%$ for selenite and from 72.65 to $55.27 \%$ in the case of selenate. Many researchers mentioned that sulfate and phosphate are the most competitive co-ions for adsorption of selenite and selenate, respectively (Das et al. 2013; Rajan 1979; Jegadeesan et al. 2005; Wijnja and Schulthess 2000; Fukushi and Sverjensky 2007). So, the material may be 


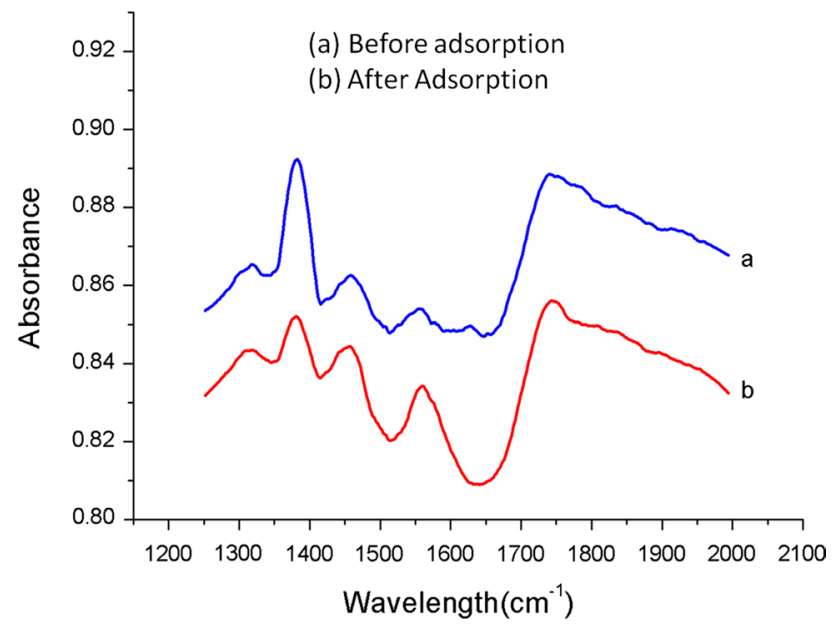

Fig. 7 FTIR spectra of MAA (before adsorption and after adsorption)

applied in the field, where lower concentrations of sulfate and phosphate are expected.

\section{Mechanism of adsorption}

Comparative FTIR spectra for MAA and Se-loaded MAA are presented in Fig. 7. In the case of MAA, distinct peaks were observed at wavelength around $3670 \mathrm{~cm}^{-1}$, between $3200-3500 \mathrm{~cm}^{-1}$ and $2400 \mathrm{~cm}^{-1}$. Peaks between $3200-3599 \mathrm{~cm}^{-1}$ and $2400 \mathrm{~cm}^{-1}$ can be assigned to different vibrations of crystalline - $\mathrm{OH}$ group, while $\mathrm{Al}-\mathrm{O}-\mathrm{H}$ stretching mode can be observed at a sharp peak at $3670 \mathrm{~cm}^{-1}$. Significant decrease in the intensity of peaks between 3200 and $3500 \mathrm{~cm}^{-1}$ has been observed after adsorption of selenium, which indicates the adsorption of selenium over MAA surface with the replacement of $-\mathrm{OH}$ group. It is a widely reported fact that oxyanions have a strong tendency to bind with $-\mathrm{OH}$ group (Meher et al. 2015). It has also been reported that the adsorption of selenium on amorphous metal oxides is through formation of inner-sphere surface complexes, which are significantly influenced by $\mathrm{pH}$ and ionic strength of the adsorbate solution (Chan et al. 2009; Wijnja and Schulthess 2000; Fukushi and Sverjensky 2007; Catalano et al. 2006; Hayes et al. 1987). This has been observed from the experimental results that adsorption of selenium drastically reduced with the increase in $\mathrm{pH}$, which also indicates that the attachment of selenium on MAA surface is through formation of inner-sphere complex with formation of $\mathrm{Se}-\mathrm{O}$ linkages. The formation of $\mathrm{Se}-\mathrm{O}$ linkage can be observed by formation of a new peak at $1650 \mathrm{~cm}^{-1}$, which is absent in raw MAA.

\section{Regeneration and reuse study}

Study of regeneration and reuse of the saturated adsorbent is important for consideration of the practical applicability in the field so that it can be used in a cost-effective manner. Oxyanions retained on the surface of activated alumina can be eluted with alkali or ammonia solution (Bansiwal et al. 2010; Pillewan et al. 2011). In the current study, $\mathrm{NaOH}$ has been studied as a regenerant. Concentration of regenerant was optimized by shaking the selenium-saturated adsorbent with different concentrations of regenerant solution for $2 \mathrm{~h}$. It was observed that elution of selenite and selenate increases with increase in $\mathrm{NaOH}$ concentration up to $0.2 \mathrm{M}$, after that no change in concentration of selenium was observed in the eluent. With the optimized eluent concentration of $0.2 \mathrm{M}$, almost all the selenite and selenate were desorbed, showing the complete regeneration of the adsorbent. It is evident from the results that up to four regeneration cycles, no significant change in the adsorption capacity $(98.34-93.35 \mu \mathrm{g}$ $\mathrm{g}^{-1}$ ) of MAA was observed. However, after the fourth cycle adsorption capacity starts gradually decreasing and falls up to $72.35 \mu \mathrm{g} \mathrm{g}^{-1}$ in the tenth regeneration cycle. Average weight loss during each regeneration cycle was measured and found to be negligible of only $0.3 \%$. The regeneration and reuse study proves the suitability of the adsorbent for column studies in a continuous flow mode.

\section{Conclusions}

MAA shows potential uptake properties to remove both selenite and selenate from water. Amorphous phase of MAA and presence of mesoporous channels leads to better surface area and more active sites for better interaction between adsorbate and the adsorbent. Adsorption isotherm data show multilayered adsorption in heterogeneous active sites of the adsorbent signifying higher adsorption capacity. Experimental data for kinetics and FTIR spectra suggest the removal of selenite and selenate through chemical interactions and formation of inner-sphere complexes. It overcomes the limitations of conventional adsorbents such as low removal efficiency for selenate and loss of removal efficiency in the presence of potential competitive anions, particularly sulfate. However, low adsorption affinity at alkaline range is still a challenging issue. Regeneration and reuse study confirms the applicability of MAA for field applications to treat drinking water contaminated with selenium, as gamma alumina is a stable phase available abundantly and is of low cost. 


\section{Compliance with ethical standards}

Conflict of interest The authors declared that they have no conflict of interest.

Open Access This article is distributed under the terms of the Creative Commons Attribution 4.0 International License (http://creativeco mmons.org/licenses/by/4.0/), which permits unrestricted use, distribution, and reproduction in any medium, provided you give appropriate credit to the original author(s) and the source, provide a link to the Creative Commons license, and indicate if changes were made.

\section{References}

Ali I (2012) New generation adsorbents for water treatment. Chem Rev 112:5073-5091. https://doi.org/10.1021/cr300133d

Anonymous (2004) Revision of drinking water quality standards in Japan (2004). http://www.nilim.go.jp/lab/bcg/siryou/tnn/tnn02 64pdf/ks0264011.pdf. Accessed 18 January 2016

Anonymous (2011) Australian drinking water guidelines (2011). https ://www.nhmrc.gov.au/guidelines-publications/eh52. Accessed 18 January 2016

Anonymous (2012) Drinking water standards and health advisories (USEPA). http://rais.ornl.gov/documents/2012_drinking_water pdf. Accessed 18 January 2016

Anonymous (2012) Indian standard: drinking water specification (IS 10500) 2012. http://cgwb.gov.in/Documents/WQ-standards.pdf. Accessed 18 January 2016

Anonymous (2014) Guidelines for Canadian drinking water quality-summary table. Water and air quality bureau, Healthy environments and consumer safety branch, Health Canada, Ottawa, Ontario. 2014:1-25. http://www.dieppe.ca/en/hoteldeville/resou rces/Canadiandrinkingwaterguidelines.pdf. Accessed 18 January 2016

Anonymous (2015a) International agency for research on cancer (IARC) monographs on the evaluation of report of the advisory group to recommend priorities for IARC monographs during 2015-2019. http://monographs.iarc.fr/ENG/Publications/inter nrep/14-002.pdf. Accessed 18 January 2016

Anonymous (2015b) Guidelines for drinking-water quality, World Health Organization (WHO) http://www.who.int/water_sanitation _health/dwq/fulltext.pdf. Accessed 18 January 2016

Awuala MR, Hasan MM, Ihara YT, Yaita T.(2014) Mesoporous silica based novel conjugate adsorbent for efficient selenium(IV) detection and removal from water. Microporous Mesoporous Mater. http://dx.doi.org/10.1016/j.micromeso.2014.07.005

Awuala MR, Hasan MM, Khaleque MA (2015) Efficient selenium(IV) detection and removal from water by tailor-made novel conjugate adsorbent. Sens Actuators, B 209:194-202. https://doi. org/10.1016/j.snb.2014.11.010

Bajaj M, Eiche E, Neumann T, Winter J, Gallert C (2011) Hazardous concentrations of selenium in soil and groundwater in North-West India. J Hazard Mater 189:640-646. https://doi.org/10.1016/j. jhazmat.2011.01.086

Bansiwal A, Pillewan P, Biniwale BR, Rayalu SS (2010) Copper oxide incorporated mesoporous alumina for defluoridation of drinking water. Microporous Mesoporous Mater 129:54-61. https://doi. org/10.1016/j.micromeso.2009.08.032

Batista JR, Young JC (1994) The influence of aqueous silica on the adsorption of Selenium by activated alumina. In: Proceedings AAWA, New York
Batista JR, Young JC (1997) Removal of Se from gold heap leachate by activated alumina adsorption EPD 97. In: Mishra B (ed) TMS, Warrendale, PA, pp 29-36

Bleiman N, Mishael YG (2010) Selenium removal from drinking water by adsorption to chitosan-clay composites and oxides: batch and columns tests. J Hazard Mater 183:590-595. https:// doi.org/10.1016/j.jhazmat.2010.07.065

Burakov AE, Galunina EV, Burakova IV, Kucherova AE, Agarwal S, Tkachev AG, Gupta VK (2018) Adsorption of heavy metals on conventional and nanostructured materials for wastewater treatment purposes: a review. Ecotoxicol Environ Saf 148:702-712. https://doi.org/10.1016/j.ecoenv.2017.11.034

Butler B (2010) Selenium treatment technologies. http://cfpub.epa. gov/si/si_public_file_download.cfm?p_download_id=497238. Accessed 18 January 2016

Catalano JG, Zhang Z, Fenter P, Bedzyk MJ (2006) Inner-sphere adsorption geometry of Se(IV) at the hematite (100)-water interface. J Coll Interface Sci 297:665-671. https://doi.org/10.1016/j. jcis.2005.11.026

CH2 M HILL (2010) Review of available technologies for the removal of selenium from water 2-223. http://namc.org/docs/00062756. PDF. Accessed 18 January 2016

Chan YT, Kuan WH, Chen TY, Wang MK (2009) Adsorption mechanism of selenate and selenite on the binary oxide systems. Water Res 43:4412-4420. https://doi.org/10.1016/j.watres.2009.06.056

Cohen RRH (2006) Use of microbes for cost reduction of metal removal from metals and mining industry waste streams. J Clean Prod 14:1146-1157. https://doi.org/10.1016/j.jclepro.2004.10.009

Das S, Jim Hendry, Essilfie-Dughan MJ (2013) Adsorption of selenate onto ferrihydrite, goethite, and lepidocrocite under neutral $\mathrm{pH}$ conditions. Appl Geochem 28:185-193. https://doi.org/10.1016/j. apgeochem.2012.10.026

Davis S, Misra M (1997) Transport model for the adsorption of oxyanions of Selenium (IV) and Arsenic (V) from water onto lanthanum- and aluminum-based oxides. J Coll Interface Sci 188:340 350. https://doi.org/10.1006/jcis.1997.4775

El-Shafey EI (2007) Removal of Se(IV) from aqueous solution using sulphuric acid-treated peanut shell. J Environ Manag 84:620-627. https://doi.org/10.1016/j.jenvman.2007.03.021

Ford KH (1987) Equilibrium, spectroscopic, and kinetic studies of ion adsorption at the oxide/aqueous interface. Thesis ( $\mathrm{Ph} \mathrm{D})$-Stanford University. https://searchworks.stanford.edu/view/1273493

Freundlich HMF (1906) Uber die adsorption in losungen. Z Phys Chem 57A:385-470

Fukushi K, Sverjensky DA (2007) A surface complexation model for sulfate and selenate on iron oxides consistent with spectroscopic and theoretical molecular evidence. Geochim Cosmochim Acta 71:1-24. https://doi.org/10.1016/j.gca.2006.08.048

Geoffroy N, Demopoulos GP (2011) The elimination of selenium (IV) from aqueous solution by precipitation with sodium sulfide. J Hazard Mater 185:148-154. https://doi.org/10.1016/j.jhazm at.2010.09.009

Ghosh MM, Cox CD, Yuan-Pan JR (1994) Adsorption of selenium on hydrous alumina. Environ Prog Sustain Energy 13:79-88. https ://doi.org/10.1002/ep.670130210

Goh KH, Lim TT (2010) Influences of co-existing species on the sorption of toxic oxyanions from aqueous solution by nanocrystalline $\mathrm{Mg} / \mathrm{Al}$ layered double hydroxide. J Hazard Mater 180:401-408. https://doi.org/10.1016/j.jhazmat.2010.04.045

Goldhaber SB (2003) Trace element risk assessment: essentiality vs. toxicity. Regul Toxicol Pharmacol 38:232-242. https://doi. org/10.1016/S0273-2300(02)00020-X

Hamilton SJ (2004) Review of selenium toxicity in the aquatic food chain. Sci Total Environ 326:1-31. https://doi.org/10.1016/j.scito tenv.2004.01.019 
Han DS, Batchelor B, Abdel-Wahab A (2011) Sorption of selenium(IV) and selenium(VI) to mackinawite (FeS): effect of contact time, extent of removal, sorption envelopes. J Hazard Mater 186:451457. https://doi.org/10.1016/j.jhazmat.2010.11.017

Hayes KF, Roe AL, Brown GE, Hodgson KO, Leckie JO, Parks GA (1987) In situ X-ray absorption study of surface complexes: selenium oxyanions on $\alpha-\mathrm{FeOOH}$. Science 238:783-786. https://doi. org/10.1126/science. 238.4828 .783

Ho YS, McKay G (1999) Pseudo-second order model for sorption processes. Process Biochem 34:451-465

Hornung SM, Yuan J, Ghosh M (1983) Se removal in fixed bed activated alumina adsorbers, In: Create a new excellence. AWWA annual conference, pp 299-318. http://nepis.epa.gov/Exe/ZyPUR L.cgi?Dockey=9101NGNV.TXT. Accessed 18 January 2016

Jain S, Bansiwal A, Biniwale BR, Milmille S, Das S, Tiwari S, Antony PS (2015) Enhancing adsorption of nitrate using metal impregnated alumina. J Environ Chem Eng 3(4A):2342-2349. https:// doi.org/10.1016/j.jece.2015.08.009

Jan YL, Wang TH, Li MH, Tsai SC, Wei YY, Teng SP (2008) Adsorption of Se species on crushed granite: a direct linkage with its internal iron-related minerals. Appl Radiat Isotopes 66:14-23. https://doi.org/10.1016/j.apradiso.2007.08.007

Jegadeesan G, Mondal K, Lalvani SB (2003) Comparative study of selenite adsorption on carbon based adsorbents and activated alumina. Environ Sci Technol 24:1049-1059. https://doi. org/10.1080/09593330309385644

Jegadeesan G, Mondal K, Lalvani B (2005) selenate removal from sulfate containing aqueous solutions. Environ Sci Technol 26:11811188. https://doi.org/10.1080/09593332608618475

Jordan N, Ritter A, Foerstendorf H, Scheinost AC, Weiß S, Heim K (2013) Adsorption mechanism of selenium(VI) onto maghemite. Geochim Cosmochim Acta 103:63-75. https://doi.org/10.1016/j. gca.2012.09.048

Kim Y, Kim C, Choi I, Rengaraj S, Yi J (2004) Arsenic removal using mesoporous alumina prepared via a templating method. Environ Sci Technol 38:924-931. https://doi.org/10.1021/es0346431

Kuan WH, Lo SL, Wang MK, Lin CF (1998a) Removal of Se(IV) and $\mathrm{Se}(\mathrm{VI})$ from water by aluminum-oxide-coated sand. Water Res 32:915-923. https://doi.org/10.1016/S0043-1354(97)00228-5

Kuan WH, Lo SL, Wang MK, Lin CF (1998b) Removal of Se(IV) and $\mathrm{Se}(\mathrm{VI})$ from water by aluminum-oxide-coated sand. Water Res 32:915-923. https://doi.org/10.1016/S0043-1354(97)00228-5

Lagergren S (1898) Zur theorie der sogenannten adsorption geloster stoffe. Kungliga svenska vetenskapsakademiens. Handlingar 24:1-39

Langmuir I (1916) The constitution and fundamental properties of solids and liquids. Part I. Solids. J Am Chem Soc 38:2221-2295

Ling L, Pan B, Zhang W (2015) Removal of selenium from water with nanoscale zero-valent iron: mechanisms of intraparticle reduction of Se(IV). Water Res 71:274-281. https://doi.org/10.1016/j.watre s.2015.01.002

Mavrov V, Stamenov S, Todorova E, Chmiel H, Erwe T (2006) New hybrid electrocoagulation membrane process for removing selenium from industrial wastewater. Desalination 201:290-296. https ://doi.org/10.1016/j.desal.2006.06.005

Meher AK, Das S, Rayalu S, Bansiwal A (2015) Enhanced arsenic removal from drinking water by iron-enriched aluminosilicate adsorbent prepared from fly ash. Desalination Water Treat 3994:1-13. https://doi.org/10.1080/19443994.2015.1112311

Mercier L, Pinnavaia TJ (1997) Access in mesoporous materials: advantages of a uniform pore structure in the design of a heavy metal ion adsorbent for environmental remediation. Adv Mater 9:500-503. https://doi.org/10.1002/adma.19970090611

Mohan D, Pittman CU (2007) Arsenic removal from water/wastewater using adsorbents-A critical review. J Hazard Mater 142:1-53. https://doi.org/10.1016/j.jhazmat.2007.01.006
Papelis C, Roberts PV, Leckie JO (1995) Modeling the rate of cadmium and selenite adsorption on micro- and mesoporous transition aluminas. Environ Sci Technol 29:1099-1108. https://doi. org/10.1021/es00004a032

Pillewan P, Mukherjee S, Roychowdhury T, Das S, Bansiwal A, Rayalu S (2011) Removal of As(III) and As(V) from water by copper oxide incorporated mesoporous alumina. J Hazard Mater 186:367-375. https://doi.org/10.1016/j.jhazmat.2010.11.008

Rajan SSS (1979) Adsorption of selenite, phosphate and sulphate on hydrous alumina. J Soil Sci 30:709-718. https://doi. org/10.1111/j.1365-2389.1979.tb01020.x

Rovira M, Giménez J, Martínez M, Martínez-Lladó X, de Pablo J, Martí V (2008) Sorption of selenium(IV) and selenium(VI) onto natural iron oxides: goethite and hematite. J Hazard Mater 150:279-284. https://doi.org/10.1016/j.jhazmat.2007.04.098

Selenium removal from ground water using activated alumina. USEPA 1980

Singh TS, Pant K (2004) Equilibrium, kinetics and thermodynamic studies for adsorption of As(III) on activated alumina. Sep Purif Technol 36:139-147. https://doi.org/10.1016/S1383 -5866(03)00209-0

Smith K, Lau AO, Vance FW (2009) Evaluation of treatment techniques for selenium removal. In: 70th annual international water conference, pp 75-92

Su T, Guan X, Gu G, Wang J (2008) Adsorption characteristics of $\mathrm{As}(\mathrm{V}), \mathrm{Se}(\mathrm{IV})$, and $\mathrm{V}(\mathrm{V})$ onto activated alumina: effects of $\mathrm{pH}$, surface loading, and ionic strength. J Coll Interface Sci 326:347353. https://doi.org/10.1016/j.jcis.2008.07.026

Su T, Guan X, Tang Y, Gu G, Wang J (2010) Predicting competitive adsorption behavior of major toxic anionic elements onto activated alumina: a speciation-based approach. J Hazard Mater 176:466-472. https://doi.org/10.1016/j.jhazmat.2009.11.052

Torres J, Pintos V, Gonzatto L, Domínguez S, Kremer C, Kremer E (2011) Selenium chemical speciation in natural waters: protonation and complexation behavior of selenite and selenate in the presence of environmentally relevant cations. Chem Geol 288:3238. https://doi.org/10.1016/j.chemgeo.2011.06.015

Trussell RA, Trussell A, Kraft P (1980) Se removal from groundwater using activated alumina, EPA-600/12-80-153. USEPA, Washington, DC

Twidwell LG, McCloskey J, Miranda P, Gale M (1999) Technologies and potential technologies for removing selenium from process and mine wastewater. In: Global symposium on recycling, waste treatment and clean technology, pp 1645-56. https://www.resea rchgate.net/publication/264856347_Technologies_and_poten tial_technologies_for_removing_arsenic_from_process_and_ mine_wastewater. Accessed 18 January 2016

Wang H, Wu T, Chen J, Zheng Q, He C, Zhao Y (2015) Sorption of $\mathrm{Se}(\mathrm{IV})$ on Fe- and Al-modified bentonite. J Radioanal Nucl Chem 303:107-113. https://doi.org/10.1007/s10967-014-3422-5

Wasewar KL, Prasad B, Gulipalli S (2009a) Removal of selenium by adsorption onto granular activated carbon (GAC) and powdered activated carbon (PAC). CLEAN Soil Air Water 37:872-883. https://doi.org/10.1002/clen.200900188

Wasewar KL, Prasad B, Gulipalli S (2009b) Adsorption of selenium using bagasse fly ash. CLEAN Soil Air Water 37:534-543. https ://doi.org/10.1002/clen.200800183

Weber WJ, Morris JC (1987) Adsorption processes for water treatment. Butterworth, London

Wei SY (2012) Surface properties and selenate adsorption of hydroxyiron-vermiculite complexes. Adv Mater Res 482-484:1201-1204. https://doi.org/10.4028/www.scientific.net/AMR.482-484.1201

Wei X, Bhojappa S, Lin LS, Viadero RC (2012) Performance of nanomagnetite for removal of selenium from aqueous solutions. Environ Eng Sci 29:526-532. https://doi.org/10.1089/ees.2011.0383

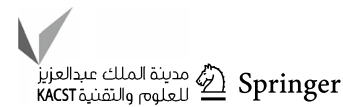


Wijnja H, Schulthess C (2000) Vibrational spectroscopy study of selenate and sulfate adsorption mechanisms on $\mathrm{Fe}$ and $\mathrm{Al}$ (Hydr) oxide surfaces. J Coll Interface Sci 229:286-297. https://doi. org/10.1006/jcis.2000.6960

Yan D, Gang DD, Asce M, Zhang N, Lin L (2013) Adsorptive selenite removal using iron-coated GAC: modeling selenite breakthrough with the pore surface diffusion model. J Environ Eng. https://doi. org/10.1061/(ASCE)EE.1943-7870.0000633

Yuan JR (1984) Adsorption of aqueous selenium and arsenic on hydrous alumina. Ph.D. Thesis, University of Missouri
Zhang L, Liu N, Yang L, Lin Q (2009) Sorption behavior of nano$\mathrm{TiO} 2$ for the removal of selenium ions from aqueous solution. J Hazard Mater 170:1197-1203. https://doi.org/10.1016/j.jhazm at.2009.05.098

Publisher's Note Springer Nature remains neutral with regard to jurisdictional claims in published maps and institutional affiliations. 